\title{
SIG PENCARIAN RUTE TERPENDEK RUMAH MAKAN HALAL DI BALI DENGAN MENGGUNAKAN METODE DIJKSTRA
}

\author{
Lutfi Ayu Ningsih ${ }^{1}$, Ely Setyo Astuti ${ }^{2}$, Ekojono $^{3}$ \\ 1,2 Teknik Informatika, Teknologi Informasi, Politeknik Negeri Malang \\ ${ }^{1}$ ayulutfi28@gmail.com, ${ }^{2}$ ely.setyo.astuti@polinema.ac.id, ${ }^{3}$ ekojono@polinema.ac.id
}

\begin{abstract}
Abstrak
Pulau Bali merupakan salah satu pulau di Indonesia sebagai tujuan wisata yang terkenal di seluruh dunia dengan keindahan pulau dan keunikan berbagai seni budayanya. Wisatawan domestik maupun mancanegara masih menjadikan Pulau Bali sebagai tempat favorit untuk berlibur. Tidak terkecuali wisatawan muslim. Wisatawan muslim dari luar daerah atau luar negeri yang melintas atau sedang berlibur di Bali terkadang masih sulit untuk menemukan lokasi Rumah Makan Halal. Selama ini wisatawan muslim tersebut masih mencari secara manual yaitu dengan cara melihat petunjuk arah atau plang nama dipinggir jalan maupun bertanya kepada beberapa orang sekitar. Dimana ini merupakan suatu permasalahan yang seharusnya segera diselesaikan oleh Pemerintah Propinsi Bali demi pelayanan masyarakat yang baik.

Untuk mengatasi permasalahan tersebut maka akan dibuatkan sebuah sistem informasi geografis untuk mencari rute terpendek menuju rumah makan halal terdekat dari posisi keberadaan saat itu. Untuk penentuan rute terpendek, aplikasi ini menggunakan metode Dijkstra. Hasil yang di harapkan dari aplikasi ini berupa informasi yang menunjukkan letak rumah makan halal beserta rute menuju rumah makan tersebut.
\end{abstract}

Kata kunci: Sistem Informasi Geografis, Aplikasi Android, Algoritma Dijkstra, Rumah Makan Halal

\section{Pendahuluan}

Pulau Bali merupakan salah satu pulau di Indonesia sebagai tujuan wisata yang terkenal di seluruh dunia dengan keindahan pulau dan keunikan berbagai seni budayanya. Secara astronomis, Bali terletak di $8^{\circ} 25^{\prime} 23^{\prime \prime}$ Lintang Selatan dan $115^{\circ} 14^{\prime} 55^{\prime \prime}$ Lintang Timur yang mebuatnya beriklim tropis serta banyak kawasan wisata pantai yang menarik dikunjungi diantaranya Pantai Kuta, Tanah Lot, Bedugul, Pulau Menjangan dan tempat wisata lainnya.

Wisatawan domestik maupun mancanegara masih menjadikan Pulau Bali sebagai tempat favorit untuk berlibur. Tidak terkecuali wisatawan muslim. Wisatawan muslim dari luar daerah atau luar negeri yang melintas atau sedang berlibur di Bali terkadang masih sulit untuk menemukan lokasi Rumah Makan Halal. Selama ini wisatawan muslim tersebut masih mencari secara manual yaitu dengan cara melihat petunjuk arah atau plang nama dipinggir jalan maupun bertanya kepada beberapa orang sekitar. Dimana ini merupakan suatu permasalahan yang seharusnya segera diselesaikan oleh Pemerintah Propinsi Bali demi pelayanan masyarakat yang baik. Pelayanan umum dalam bentuk Rumah Makan Halal sangatlah penting bagi masyarakat muslim. Karena dalam islam memakan suatu makan harus berhati-hati termasuk memperhatikan apakah makanan tersebut halal atau tidak. Capat dalam menemukan lokasi merupakan hal penting yang harus diperhatikan. Karena lelah dalam perjalanan membutuhkan tempat makan dan istirahat yang segera. Untuk mengatasi permasalahan tersebut maka akan dibuatkan sebuah sistem informasi geografis untuk mencari rute terpendek menuju rumah makan halal terdekat dari posisi keberadaan saat itu. Dalam pencarian jarak terdekat pada sistem ini menggunakan algoritma Dijkstra. Algoritma Dijkstra adalah algoritma pencarian graf yang memecahkan masalah jalur terpendek yang bersumber dari satu simpul untuk sebuah graf dengan bobot simpul tidak boleh negatif.

\section{Algoritma Dijkstra}

Algoritma Dijkstra (dinamai menurut seorang ilmuan computer Edsger Dijkstra) adalah sebuah algoritma rakus (greedy algorithm) yang dipakai dalam memecahkan permasalahan jarak terpendek (shortest past problem) untuk sebuah graft berarah (directed graph) dengan bobot-bobot sisi (edge weights) yang bernilai tak-negatif. Misalnya, bila vertices dari sebuah graf melambangkan jarak antara kota-kota dan bobot sisi (edge weights) melambangkan jarak antara kota-kota tersebut, maka algoritma Dijkstra dapat digunakan untuk menentukan jarak terpendek antara dua kota.

Input algoritma ini adalah sebuah graf berarah yang bebobot (weighted directed graph) $\mathrm{G}$ 
\& sebuah sumber vertex s dalam $\mathrm{G} \& \mathrm{~V}$ adalah himpunan vertices dalam graph $\mathrm{G}$.

Setiap sisi dari graf ini adalah pasangan vertices $(\mathrm{u}, \mathrm{v})$ yang melambangkan hubungan dari vertex v. himpunan semua tepi disebut $\mathrm{E}$.

Bobot (weights) dari semua sisi dihitung dengan fungsi

$\mathrm{W}: \mathrm{E} \longrightarrow[0, \infty]$

Jadi $\mathrm{w}(\mathrm{u}, \mathrm{v})$ adalah jarak tak-negatif dari vertex $\mathrm{u}$ ke vertex $\mathrm{v}$.

Ongkos (cost) dari sebuah sisi dapat dianggap sebagai jarak antara dua vertex, itu jumlah jarak semua sisi dalam jalur tersebut. Untuk sepasang vertex $\mathrm{s}$ dan $\mathrm{t}$ dalam $\mathrm{V}$, algoritma ini menghitung jarak terpendek dari s ke t.

Berikut adalah langkah-langkah perhitungan Algoritma Dijkstra:

a. Inisialisasi

$$
\begin{aligned}
& \mathrm{N}=\{\mathrm{s}\} \\
& \mathrm{D} j=\mathrm{C} s j, \forall j \neq s \\
& \mathrm{D} s=0
\end{aligned}
$$

Rumus 1.2 merupakan bentuk suatu array/himpunan $\mathrm{N}$ dengan anggota $\mathrm{s}$ (s adalah lambang untuk suatu node sumber). Nilai D adalah jarak yang akan tersedia pada tabel hasil algoritma, sementara $\mathrm{C}$ adalah nilai jarak pada map yang tersedia. Maka pada tahap inisialisasi ini nilai $\mathrm{Dj}$ (jarak pada hasil tabel antara node $\mathrm{s}$ dengan node $\mathrm{j}$, tak sama dengan s) dimasukkan nilai yang sebenarnya. Jika tersambung secara langsung maka akan dianggap tak tersedefinisi. Untuk jarak Ds tentu saja bernilai 0 .

b. Temukan smpul tetangga (node selain sumber)

$$
D i=\min _{j € N} D j
$$

Untuk perulangan tiap baris dimasukkan node I yang belum termasuk pada array/himpunan $\mathrm{N}$ untuk nanti node I tersebut dijadikan sebagai "perpanjangan" dari node s, dengan node I juga adalah node tetangga dari node s. node I yang dimasukkan pada himpunan $\mathrm{N}$ berdasarkan pada jarak terkecil dengan node $\mathrm{s}$. dan jika seluruh node sudah masuk dalam himpunan $\mathrm{N}$, maka iterasi akan berhenti yang ditunjukkan pada rumus 1.5.

c. Ganti nilai untuk setiap $\mathrm{j} € \mathrm{~N}$

$$
D i=\min \{D j, D i+C i j\}
$$

Untuk setiap node $\mathrm{j}$ (dalam tabel hasil: tiap kolom) dipengaruhi nilainya yang paling kecil dan dibandingan antara nilai $\mathrm{Dj}$ sebelumnya dengan hasil penjumlahan (Di+Cij), itu penjumlahan jarak node $\mathrm{s}$ ke node $\mathrm{i}$ dengan jarak sebenarnya dari node i ke node $\mathrm{j}$.

\section{Metodologi}

Metodologi pengembangan pada aplikasi Pencarian Rumah Makan Halal di Bali menggunakan metode waterfall. Model air terjun atau Waterfall menyediakan pendekatan alur hidup perangkat lunak secara sekuensial atau terurut mulai dari analisis, desain, implementasi dan pengujian (Shalahudin, 2011:26).

1) Mendefinisikan Kebutuhan (Requerement Definition)

Aplikasi yang akan dibuat adalah aplikasi pencarian rumah makan halal dengan menerapkan metode Dijkstra sebagai pencarian jarak terpendek dari titik awal user dengan rumah makan terdekat.

2) Mendesain sistem dan software (System and Software Design)

Perancangan (design) dapat digunakan untuk mempermudah dalam pembuatan system, sehingga memiliki standar atau acuan dalam proses pembuatan program. Gambar 1 merupakan flowcart sistem informasi pencarian rumah makan halal:

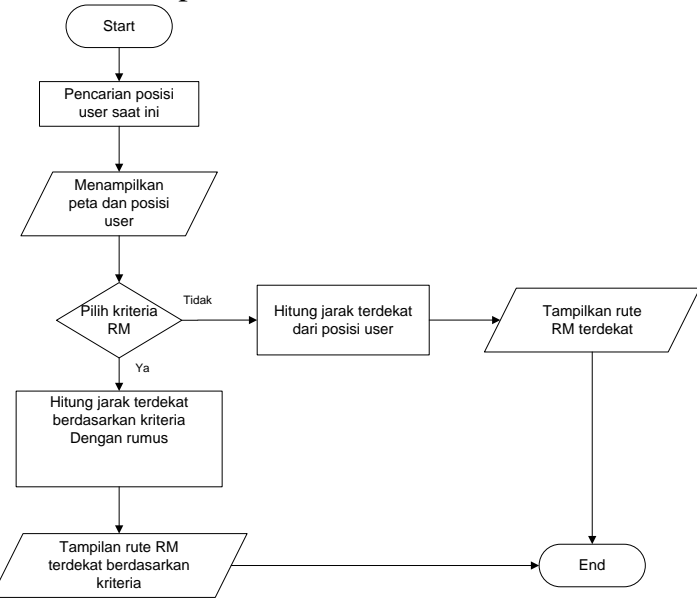

Gambar 1: Flowchart Sistem Informasi Geografis

Pencarian Lokasi Rumah Makan Halal

Dalam use case yang ditunjukkan pada Gambar 2 menerangkan bahwa terdapat dua aktor admin dan user. Admin bertugas mengelola data pada web service sedangkan user hanya bisa melihat rute rumah makan halal pada maps.

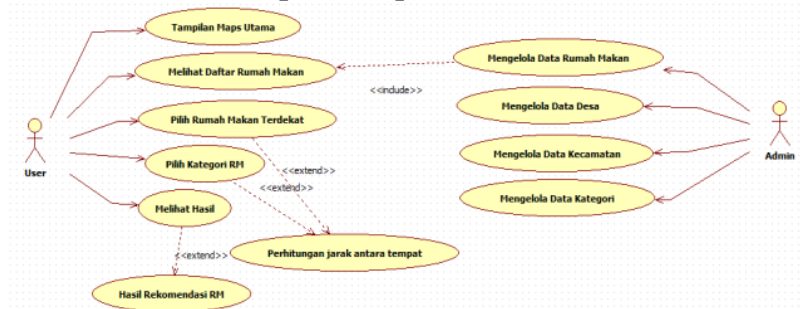

Gambar 2: Use Case Sistem Informasi

Geografis Pencarian Lokasi Rumah Makan Halal

Berikut adalah gambaran Entity Relationship Diagram (ERD) dari Sistem Informasi Geografis Pencarian Lokasi Rumah Makan Halal: 


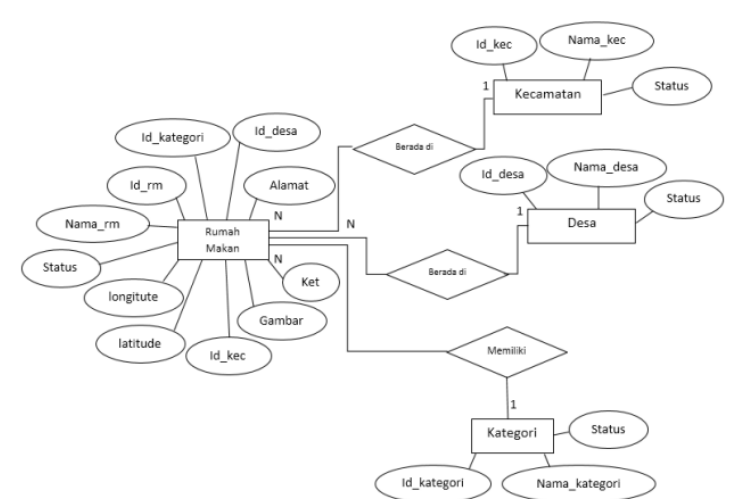

Gambar 3 : Entity relationship diagram (ERD) sistem informasi geografis pencarian lokasi rumah makan halal

ERD yang digunakan untuk merancang Sistem Informasi Geografis Pencarian Lokasi Rumah Makan Halal ini terdiri dari empat tabel yang direlasikan membentuk sebuah diagram ER. Setiap Rumah Makan berada di suatu desa dan kecamatan yang digambarkan dengan relationship berisikan "Berada di" sehingga primery key yang berada pada entitas desa dan entitas kecamatan menjadi foreignkey (kunci tamu) pada entitas Rumah makan. Dan juga pada Setiap rumah makan memiliki kategori untuk mengelompokkan rumah makan tersebut yang digambarkan dengan relationship berisikan "Memiliki" sehingga primery key yang berada pada kategori menjadi foreignkey (kunci tamu) pada entitas Rumah makan yang digambarkan pada Gambar 3.

3) Implementasi dan pengujian unit

(Implementation and Unit Testing)

Tahapan berikutnya adalah dengan mengimplementasikan desain yang sudah dibuat dalam sebuah program. Dalam implementasi ini proses pembuatan pertama yaitu pengimplementasian database kedalam sistem, pembuatan webservice, pembuatan interface $\mathrm{di}$ android dan yang terakhir adalah pengimplementasian metode Dijkstra untuk mencari jarak terdekat rumah makan dari posisi user saat itu.

4) Integrasi dan Pengujian Sistem (Integration and System Testing)

Tahapan selanjutnya adalah mengintegrasikan unit program yang telah dibuat menjadi sebuah sistem. Selanjutnya, dilakukan pengujian sistem secara keseluruhan.

\section{A. Halaman Global Maps}

Halaman Global Maps merupakan halaman yang digunakan user untuk mengetahui maps/peta secara global pada kabupaten jembrana yang dimana pada peta tersebut sudah ada titik-tiitik rumah makan halal.

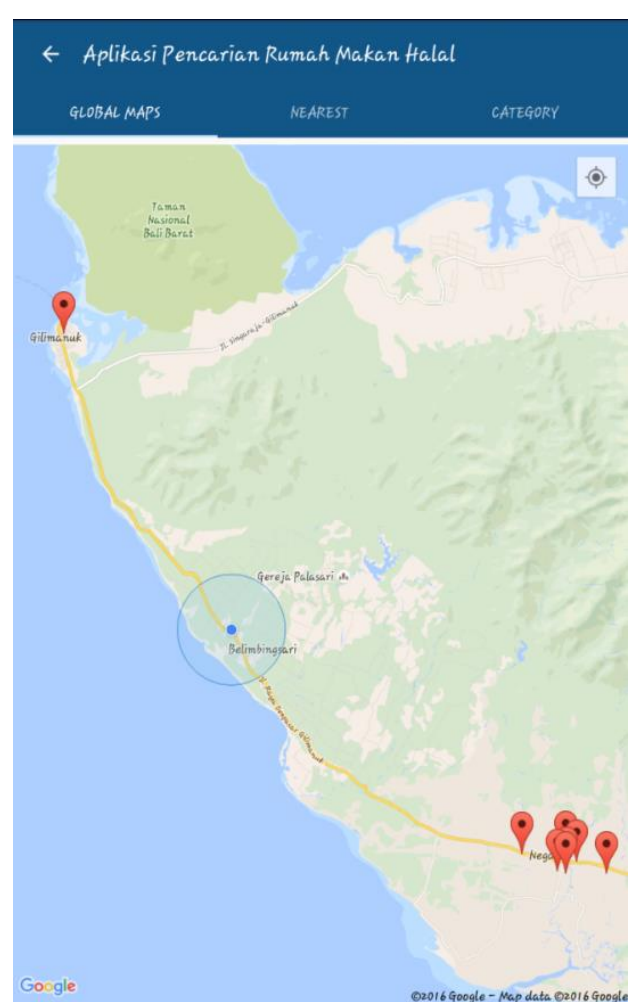

Gambar 4: Halaman Global Maps

Pada gambar 4 terdapat 8 titik rumah makan yang terdapat kabupaten Jembrana, diantaranya adalah:

Rumah makan Anisa

Rumah makan Barokah

Rumah makan Puas

Rumah makan Sahara

Rumah makan Bidadari

Rumah makan Madina

Rumah makan Bu Nur

8. Rumah makan Ayam Betutu Bu Lina

\section{B. Halaman Nearest}

Halaman ini merupakan halaman yang digunakan user untuk mengetahui rute / jarak rumah makan halal terdekat pada titik user saat itu. Data sampel untuk pengujian yang di gunakan adalah sebagai berikut:

Tabel 1: Data jarak tiap titik rumah makan halal menurut meter

\begin{tabular}{|c|c|c|c|c|c|c|c|c|c|}
\hline $\begin{array}{l}\text { No } \\
\text { de }\end{array}$ & PA & $\begin{array}{c}\text { RM } \\
\text { An } \\
\text { Nisa } \\
\end{array}$ & $\begin{array}{l}\text { RM } \\
\text { Baro } \\
\text { Kah } \\
\end{array}$ & $\begin{array}{l}\text { RM } \\
\text { Puas }\end{array}$ & $\begin{array}{c}\text { RM } \\
\text { Sahara }\end{array}$ & $\begin{array}{c}\text { RM } \\
\text { Bida } \\
\text { dari } \\
\end{array}$ & $\begin{array}{c}\mathrm{RM} \\
\mathrm{Ma} \\
\text { dina } \\
\end{array}$ & $\begin{array}{c}\mathrm{RM} \\
\mathrm{Bu} \\
\mathrm{Nur} \\
\end{array}$ & $\begin{array}{c}\mathrm{RM} \\
\mathrm{Bu} \\
\mathrm{Lina} \\
\end{array}$ \\
\hline 1 & \multirow{11}{*}{$\begin{array}{c}\text { Pan } \\
\text { tai Ba } \\
\text { luk Re } \\
\text { ning }\end{array}$} & 120 & 120 & 120 & 120 & 120 & 120 & 120 & 4500 \\
\hline 2 & & 3000 & 3000 & 3000 & 3000 & 3000 & 3000 & 3000 & 23500 \\
\hline 3 & & 750 & 1100 & 1100 & 750 & 1100 & 1100 & 1100 & 450 \\
\hline 4 & & 1000 & 5400 & 5400 & 1000 & 5800 & 3430 & 5200 & \\
\hline 5 & & 900 & 260 & 350 & 900 & & & 350 & \\
\hline 6 & & 1500 & & 350 & 1500 & & & & \\
\hline 7 & & 900 & & 1300 & 900 & & & & \\
\hline 8 & & 270 & & & 270 & & & & \\
\hline 9 & & 260 & & & 110 & & & & \\
\hline 10 & & 200 & & & 210 & & & & \\
\hline 11 & & 140 & & & & & & & \\
\hline & Jumlah & 9040 & 9880 & 11620 & 8760 & 10020 & 7650 & 9770 & 28450 \\
\hline
\end{tabular}


Contoh pada perbandingan antara titik awal adalah Pantai Baluk Rening dan tujuan akhirnya adalah rumah makan halal terdekat. Rumah makan halal dipilih dua yang pemilihan jarak rumah makan dipilih

Untuk mencari nilai jumlah = node1+node2+......+nodeN

Rumah Sahara (memiliki 10 node):

$120+3000+750+1000+900+1500+900+270+$

$110+210=8700$ meter

Rumah Makan 2 (memiliki 4 node):

$120+3000+1100+3430=7650$ meter

Dalam Tabel 1 menerapkan metode Dijkstra dimana jarak antara 2 rumah makan dibandingkan. Data nilai yang di ambil meliputi nilai jumlah dan rata rata. Sehingga di cari nilai minimum dari ke-2 perbandingan antar 2 rumah makan.

Gambar 5 merupakan hasil perhitungan yang diterapkan pada aplikasi pencarian rumah makan halal.

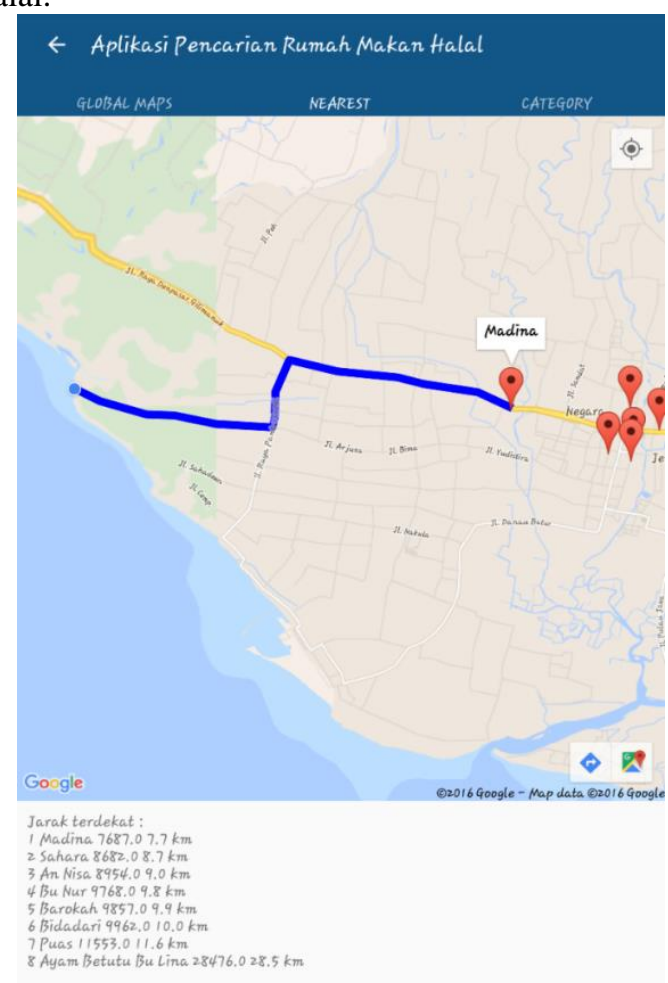

Gambar 5: Halaman Nearest

\section{Halaman Category}

Halaman Category merupakan halaman yang digunakan user untuk memilih kategori yang diinginkan.

Terdapat 2 kategori diantaranya Javanees Food dan Balinees Food. Pada Gambar 6 terdapat rute untuk mencari rumah makan halal terdekat menurut Javanes Food.

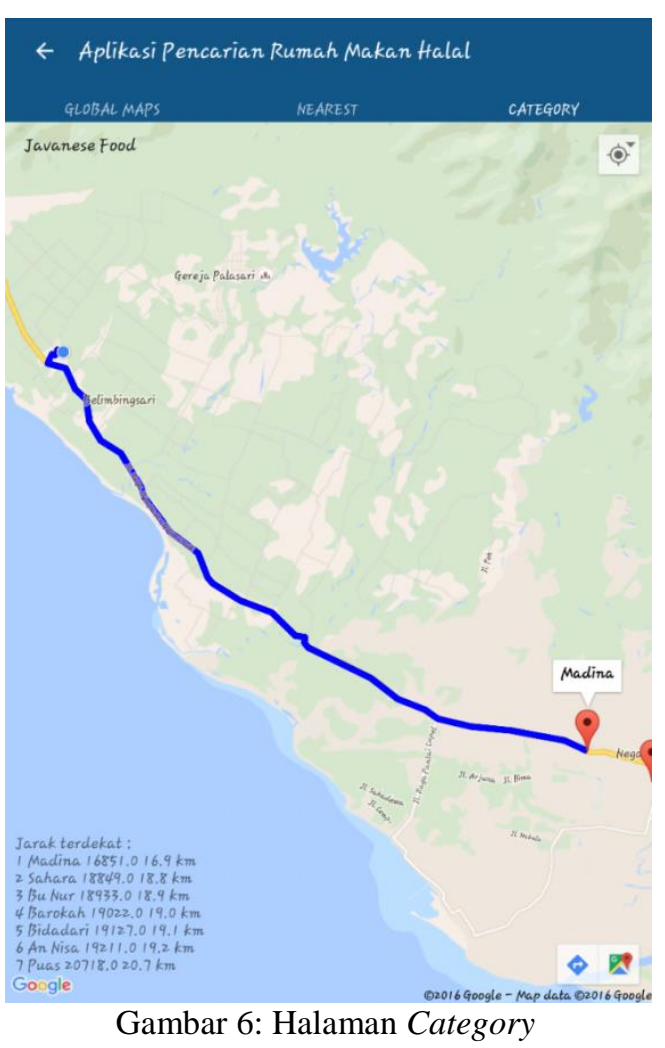

4) Pengoprasian dan Perawatan (Operation and Maintenance)

Tahapan yang terakhir adalah pengoprasian dan perawatan sistem. Perawatan / pemeliharaan suatu software diperlukan termasuk di dalamnya adalah pengembangan/ penambahan fitur - fitur yang belum ada pada software tersebut. Pengembangan diperlukan ketika adanya perubahan dari eksternal perusahaan seperti ketika ada pergantian sistem operasi atau perangkat lainnya

\section{Kesimpulan dan Saran}

\subsection{Kesimpulan}

Berdasarkan penelitian yang telah diakukan pada Sistem Informasi Geografis Pencarian Rumah Makan Halal Di Bali Menggunakan Metode Dijkstra dapat diambil kesimpulan sebagai berikut:

a. Sistem informasi geografis dapat memberikan informasi rute terdekat rumah makan halal yang dituju.

b. Metode Dijkstra dapat membantu pengguna dalam mencari rumah makan halal terdekat.

c. Dari perolehan kuisioner yang sudah disebarkan maka didapatkan prosentase ratarata sebesar $84.8 \%$, dapat disimpulkan bahwa tujuan dalam pembuatan aplikasi pencarian rumah makan halal sudah tercapai.

\subsection{Saran}

Penelitian ini masih dapat di kembangkan menjadi sistem yang lebih kompleks lagi, dan tidak hanya berfokus pada 1 kabupaten saja dan 
penambahan variabel baru meliputi keadaan jalan, pusat oleh - oleh, pariwisata, dan lain - lain. Sehingga Sistem Informasi Geografis ini menjadi lengkap.

\section{Daftar Pustaka:}

Afifudin.'Perancangan Sistem Informasi Geografis Daerah Banjir Kabupaten Lamongan" [Online] Tersedia: http://www.vedcmalang.com/pppptkboemlg /index.php/menuutama/teknologiinformasi/804-perancangan-sistem-informasigeografis-daerah-banjir-kabupaten-lamongan [12 April 2016]

Jadibaru. "Web Service" [Online] Tersedia: http://www.jadibaru.com/android/ pengenalanandroid-studio-2/ [11 April 2016]

Prahasta, Eddy 2009. Sistem Informasi Geografis Konsep Dasar-Dasar (Perspektif Geodesi \& Geomatika). Bandung: Informatika

Salahuddin, 2011. Modul Pembelajaran Rekyasa Perangkat Lunak (Tersetruktur dan Berorientasi Objek). Penerbit Modula. Bandung.

Safaat H, Nazruddin 2014. Pemrograman Aplikasi Mobile smartphone dan Tabelt PC Berbasis Android. Bandung: Informatika

Setiawan, Willy 2011. Pembahasan Pencarian Lintasan Terpendek Menggunakan Algoritma Dijkstra dan A*. Bandung: Institut Teknologi Bandung

Supriyanto. "Algoritma Dijkstra di Java C/C++Python PHP" [Online] Tersedia: http://www.metode-

algoritma.com/2013/02/algoritma-dijkstra.html [4 Desember 2015]

Wibowo, Bambang Teguh 2014. Aplikasi Penentuan Jalur Terpendek Untuk Pemadam Kebakaran Dengan Menggunakan Metode Dijkstra. Medan, STMIK Budi Darma Medan 